Article

\title{
The Importance of Renewable Energy Sources in Poland's Energy Mix
}

\author{
Renata Marks-Bielska ${ }^{1, *(\mathbb{D})}$, Stanisław Bielski ${ }^{2}{ }^{2}$, Katarzyna Pik ${ }^{1}$ and Krystyna Kurowska ${ }^{3}$ (D) \\ 1 Department of Economic Policy, Faculty of Economic Science, University of Warmia and Mazury in Olsztyn, \\ Oczapowskiego 4, 10-719 Olsztyn, Poland; kasia.pik01@gmail.com \\ 2 Department of Agrotechnology, Faculty of Environmental Development and Agriculture, \\ Agricultural Production Management and Agribusiness, University of Warmia and Mazury in Olsztyn, \\ Oczapowskiego 8, 10-719 Olsztyn, Poland; stanislaw.bielski@uwm.edu.pl \\ 3 Department of Spatial Analysis and Real Estate Market, Faculty of Geoengineering, University of Warmia \\ and Mazury in Olsztyn, Prawocheńskiego 15, 10-695 Olsztyn, Poland; krystyna.kurowska@uwm.edu.pl \\ * Correspondence: renatam@uwm.edu.pl; Tel.: +48-89-523-47-09
}

Received: 10 August 2020; Accepted: 3 September 2020; Published: 5 September 2020

\begin{abstract}
Exploitation of renewable energy sources for power generation has been more and more important in recent years. This results from the economic issues and the measures taken to ensure the energy security. The aim of this research was to determine the significance of renewable energy sources (RES) in the energy mix of Poland, and to elicit the opinions and the level of knowledge of the society on the use and development of non-conventional energy. The article also presents advantages and disadvantages of types of RES, the obstacles which hinder the progress of green energy in Poland, and the proposed measures to expand the share of the RES in the overall energy mix. The research relied on the statistical data gathered by Statistics Poland. The opinions of respondents were elicited through a diagnostic survey based on a questionnaire. The research has demonstrated that the respondents support the development of RES in Poland. However, they also maintain that the purchase and installation of devices for the production of non-conventional energy are too expensive. The respondents believe that in order to increase the number of green power plants, subsidies to encourage RES investment and tax reliefs related to this investment should be bigger.
\end{abstract}

Keywords: energy; renewable energy sources; energy mix

\section{Introduction}

Ever since the industrial revolution in Europe, the use of fossil fuels has been on the rise, along with the growth of the population and the improvement in living standards [1]. Dynamic development of national economies requires a significant increase in the demand for energy. Consumption of fossil resources for generation of heat and electricity production equals ca. $75 \%$, for producing fuels-around $20 \%$, and only a few percent are used to make chemicals and other materials [2]. Conventional energy resources, like carbon, natural gas, and oil, are no longer sufficient to satisfy the demand of the global economy [3]. A rapid increase of energy intensity in many industries may cause the exhaustion of these resources. Experts warn that with the current consumption of energy, non-renewable resources may be used up as soon as 2040 [4]. Power generation in Poland is mostly based on the combustion of hard coal and lignite; therefore, as the probability of their exhaustion seems real and in order to meet the obligations towards the European Union, the government of Poland should intensify its actions to promote renewable energy sources (RES) in the country.

Another related issue is the growing pollution of the environment and the climate change caused by conventional sources of energy [5-7]. During the process of power generation based on 
conventional resources, many hazardous substances are released into the waters and atmosphere; besides, the environment is polluted by dust. Thus, many organizations like the European Union (EU) have begun implementing measures to protect the natural environment and promote alternative solutions for non-conventional energy sources. The modern society is more aware of the growing environmental problems on the global scale. This leads to the growing interest in energy from renewable sources [8], or generated from solar radiation, wind, biomass, water, and geothermal sources. Renewable sources of energy come in an unlimited supply, they do not emit greenhouse gasses into the atmosphere, or only a negligible amount thereof, and they are less expensive than the conventional sources.

For every national economy, attaining energy security is an ultimate goal $[9,10]$. This term means the ability of the market economy to achieve the potential to cover all current and future needs of the recipients for fuel and energy. Energy security of every country means that it is able to provide sufficient amounts of electricity for a price its recipients are capable of paying, with a simultaneous respect for principles of nature conservation. The definition of energy security is dynamic and contextual. The scope of energy security has been extended to place emphasis on dimensions such as environmental sustainability and energy efficiency [11,12].

Green energy production in Poland is based on biofuels (around 80\%), and wind energy generation has a relatively large share as well $(12 \%)$. Much less energy originates from waterpower $(2 \%)$, biogas $(2.88 \%)$, and solar power $(0.68 \%)$, and trace amounts of energy come from incineration of municipal waste, geothermal springs, and heat pumps [13].

The development of RES in a country guarantees access to the local and renewable resources. In consequence, the country has more resources for energy production, and, in times of a crisis resulting not only from the depletion of energy sources, but also from various political and economic conflicts, it becomes independent of the import of resources from abroad [14].

Poland, like everywhere else in the world, has witnessed a positive trend of the increasing share of renewable energy in the energy mix of the economy. This development is encouraged by the national and EU legislation, the advent of new technologies in the energy industry, increased awareness of ecology and nature conservation in the society, and last but not least, the creation of favorable conditions for RES micro-installations.

In 2018-2019, the development of photovoltaics was affected by new legal regulations, which enabled the full launch of an auction system and grants from national programs, including 'My electricity'. The forecasts prepared by the Institute of Renewable Energy indicate that in the years 2021-2022, which coincide with the finalization of projects that won the auctions in 2018-2019, most investments will focus in the sector of photovoltaic farms. In 2019, photovoltaics recorded the highest increase in installed power among all RES, which means it is now the main investment area in renewable energy generation. In 2025, the total installed power in photovoltaics can reach 7.8 GW [15].

The study by Bódis et al. [16] suggests that Poland has a good potential for the development of photovoltaics, mostly considering the country's geographical location and climatic zone (similar location to Germany's, which is the leading country in RES) [17]. Other scientists report that Poland has suitable meteorological conditions for the development of wind farms [18]. Land wind farms will be developing less dynamically than before, but windmills on the Baltic Sea are a promising option. The wind reaches relatively high velocities there and does not encounter obstacles, thus offshore wind farms are more productive than land ones. However, the investment in offshore wind farms is not feasible until the transmission grid in the northern part of Poland is reinforced so as to be able to transmit the generated power inland [13]. This is especially important in the context of halting the intensive increase in wind power generation observed in 2017, which was due to certain legal regulations that investors in wind farms considered discouraging, such as restrictions concerning the location and construction of land wind farms, with special emphasis laid on spatial management principles, natural environment protection, and diminishing the negative impact on the environment 
and surrounding areas [18-20]. It is important to reconcile interests of an investor and of residents living in the vicinity of an investment project.

The share of green energy in Poland's energy mix could be further expanded in the countryside, which would take advantage of their convenient conditions (geographical location-vast countryside) as well as multidirectional use of green energy (electricity, heat, and biofuel). The countryside could become independent of energy and fuel supplies, and a RES investment would definitely create additional jobs and activate local communities to act for the sake of the environment [21].

There are other limitations to the development of RES, including photovoltaics and wind power, in Poland. The major ones are the lack of the state's stable policy towards the RES sector (coal phase-out progressing too slowly-in 2019, coal made up 77\% of all energy carriers used in Poland, and high costs of implementation of investments, as well as complicated formal and legal procedures). At present, the share of green energy in Poland's energy mix is not sufficient. The factors hindering the use of non-conventional energy sources are high financial cost, lengthy administrative procedures, and inadequate legislation [22]. With regard to these obstacles, the Polish government should create more favorable conditions for the development and expansion of green energy through legislation to reduce the process of launching new installations, and to implement legal measures to reduce the cost of such installations.

The aim of the research was to determine the significance of renewable energy sources in the energy mix of Poland, and to elicit the opinions and the level of knowledge of the respondents on the use and development of non-conventional energy.

\section{Materials and Methods}

In times of the appreciation of a clean natural environment, its influence on human life and health, and under the threat of the exhaustion of fossil sources of energy and ever-declining quality of the Earth's climate, the use of renewable sources of energy and their impact on human health and energy security of Poland become ever more important $[23,24]$. Another incentive to encourage the share of renewable energy is the EU legislation and its norms imposed to motivate the protection of the clean environment.

The research relied on the method of a diagnostic survey, including a questionnaire, and on the processing of relevant source materials, i.e., statistical data. The questionnaire was designed to study the state of knowledge and individual opinions of Poles on the renewable sources of energy, the opportunities for growth, and factors which may contribute to a low share of RES in Poland's energy mix.

The study was conducted in August 2019, and it involved 236 respondents. The scope of the questionnaire concerned the current and general knowledge of the renewable energy sources in Poland and the respondents' opinions about opportunities for the development of this type of energy. The questionnaire was addressed to urban and rural residents of Poland. The respondents supplied their answers in person or online.

To obtain a deep insight into the subject, statistical data generated in an analysis of Poland's energy mix performed by Statistics Poland were considered. The data enabled us to demonstrate a shift in the share of renewable energy in Poland's energy mix.

\section{Results and Discussion}

\subsection{Concept and Types of Energy: Classification of Energy}

The satisfaction of energy needs is important to every man. For instance, without solar radiation, life on Earth would not be possible. Man has long used available natural resources as energy sources. Even primitive humans learned to use available natural resources to ease the conditions and improve the quality of their lives. Only after the industrial revolution did people begin to give more importance to conventional energy sources [25]. The development in power generation led to significant scientific and 
technical revolutions, e.g., the development of industry and electricity production. These developments in turn, as well as the growing population, caused an increased demand for energy.

Energy means capability to do mechanical, electrical, or other work, where different types of activities are propelled by different types of energy [26]. The relevant literature classifies energy as renewable and non-renewable.

\subsubsection{Non-Renewable Energy}

Conventional energy is generated through the use of non-renewable resources of energy, or those which cannot regenerate in a short period of time. This means that their utilization happens more rapidly than their replenishment [27]. The most important of these are: hard coal and lignite, natural gas, uranium, and oil.

Fossil fuels have long satisfied energy needs in energy-intense spheres of human life (Figure 1). However, the dynamic growth of national economies and the increase in the environment pollution called for a need to seek alternatives to these non-renewable resources.

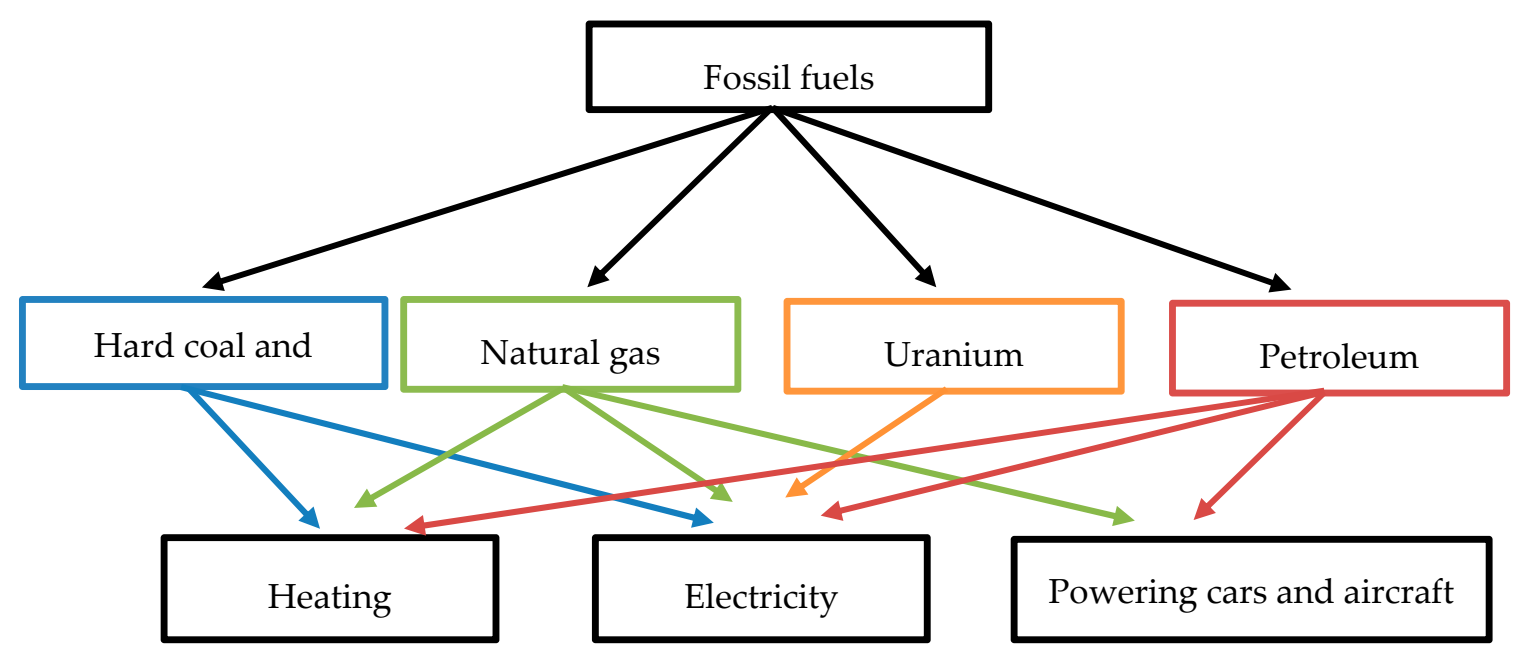

Figure 1. Types of fossil fuels and their use. Source: developed by the authors, based on Reference [27].

Millions of years ago, in a natural process, plants turned into carbon or a sedimentary rock of organic origin. There are many varieties of carbon, of which the most popular are: peat, lignite, and hard coal. Lignite has a higher caloric value than peat. It is used as an inexpensive heating material and for production of wax, petrol, and other synthetic materials [28]. Hard coal contains $75-79 \%$ of carbon elements. It can come in diverse chemical composition, depending on the type and location [29]. This fossil resource has a wide range of applications, as it is used not only in energy production, but also in everyday life.

The measures undertaken by the Polish state in the energy sector have long focused on the extraction and processing of the two types of coal, which is why Poland belongs to global leaders in coal mining. Of the energy in Poland, $88 \%$ originates from the processing of these resources. Poland has the advantages of having rich deposits and experience in extraction, as well as the scientific, engineering, and technical support, which guarantees access to modern machinery. The cost of producing energy out of these fossil resources is negligible in comparison to other technologies. The coal reserves Poland has ensure access to electricity and heating for the next 25-50 years, which guarantees energy independence [30]. The advantages of coal for the production of electricity can be stated as follows:

- Of all non-renewable energy sources worldwide, coal reserves are the largest

- No hazard related to transport, storage, and use

- Low price

- Combustion generates a great deal of energy and heat 
The disadvantages of using coal in power generation are:

- Emission of carbon dioxide into the atmosphere during power generation

- Limited reserves

- Negative impact on the natural environment (e.g., acid rains)

- Degradation of landscape

- Emission of dust [31]

In Regulation 1099/2008 of the European Parliament and the Council of 22 October 2008, natural gas was defined as an underground deposit gas which may take gaseous or liquid form. The 20th century witnessed a growing demand for this material, both in many industries and in private households. As the coal deposits in Poland are large, the use of gas is relatively low. For the sake of the environment, it is worth noting that the use of natural gas should be significantly expanded, as it emits less harmful greenhouse gases than coal [32]. The benefits of using natural gas in energy generation are:

- High efficiency

- Short construction time of power plants

- Versatility

- Low price

- $\quad$ Ease of transport [33]

Despite its many benefits, natural gas must be handled carefully, as it is poisonous in high concentration. Besides, carbon dioxide is emitted into the atmosphere during the combustion of natural gas, though such emissions are lower than in other non-renewable energy sources. Another disadvantage of natural gas is the high cost of energy generation, which follows from the unstable cost of fuels [34].

Petroleum is believed to be one of the essential sources of energy. It determines the energy market and energy security countrywide. Petroleum in Poland is mostly imported. The national deposits are too small to ensure the energy security of the country. Poland's deposits satisfy merely $3 \%$ of the national demand for this resource. The main supply of petroleum comes through the Druzhba pipeline, which connects Siberia with Central Europe and further with Germany, to which petroleum is supplied through the territory of Poland. In recent years, the development of the energy infrastructure in Poland has concentrated on the expansion of storage capacity for petroleum and liquid fuels. Such measures positively contribute to a greater energy security of the country [35]. Among the disadvantages of using petroleum in energy generation are:

- Risk of failure or leakage during extraction or transport

- Emission of hazardous compounds into the atmosphere during combustion

- High cost of power generation

- Dependency on petroleum exporters

The benefits are:

- Direct exploitation of deposits

- Convenient distribution through pipelines

- $\quad$ Easy storage [34]

Uranium belongs to the chemical group of actinides. It is widespread in the earth's crust. It can also be found in ocean waters in large amounts, but in low concentration. The largest deposits of this element are in Australia, Kazakhstan, Canada, and Russia [36]. Uranium is used in the generation of nuclear power. In Poland, it can be found in Podlasie in the village of Rajsk, and in the Sudety mountains, e.g., in Kowary mine. The benefits of nuclear power are as follows:

- Low failure rate of power plants 
- Low emission of pollutants

- Low consumption of fuel

- High concentration of power

- Long operating life (provision of a large number of jobs)

The shortcomings of this type of energy are:

- $\quad$ Radiation risk

- High cost of safety measures

- High cost of storage of radioactive waste

- Public concern [34]

A review of the literature provides many examples of advantages and disadvantages of conventional energy. The greatest advantages of non-renewable energy are:

- Relatively low cost of power generation

- Technological competence

- High volume and power per unit of mass

- Accessibility of energy resources

The most often cited disadvantages are:

- Air pollution due to exhaust emissions into the atmosphere

- Global contamination risk of nuclear power plant failures

- Exhaustion of fossil fuels

- Problems with waste storage (mostly radioactive)

- Irreversible changes to landscape [26]

\subsubsection{Renewable Energy}

Renewable energy is energy generated through natural processes. It is generated by exploitation of renewable energy resources, i.e., solar radiation, water, wind, energy from solid and liquid biomass, geothermal energy, and tidal and ocean currents [37]. An increase in the general consumption and an acceleration in the shift from conventional to renewable energy are stimulated by environmental motives. Non-conventional sources, unlike non-renewable ones, do not produce energy residues, i.e., sulfur monoxide and dust emitted into the atmosphere. Despite the constant progress in the energy generation technology, no emission-free devices have yet been invented. A significant advantage of RES, in times of increased energy expansion, is the fact that they are inexhaustible and their deposits have remained stable since the beginning of the Earth and Solar System (Table 1).

The accessibility of renewable energy sources is determined by the local topography, the extent of woodland and farmland, number of bodies of water, and geographical location. As these factors come into play, the accessibility and amount of renewable energy sources differs across the country [38].

There are two types of hydropower which exist in the natural environment: one related to rivers and the other one to oceans. In the first case, electricity is generated in river power plants, where the velocity of a water flow and the difference in water levels of the rivers are exploited. In the case of ocean energy generation, turbines are propelled by movements of water resulting from tides, waves, and ocean currents (Figure 2). 
Table 1. Classification of renewable energy sources.

\begin{tabular}{|c|c|c|c|c|}
\hline \multicolumn{2}{|c|}{$\begin{array}{c}\text { Primary Sources of } \\
\text { Energy }\end{array}$} & $\begin{array}{l}\text { Natural Energy } \\
\text { Transformations }\end{array}$ & $\begin{array}{l}\text { Technical Energy } \\
\text { Transformations }\end{array}$ & $\begin{array}{c}\text { Form of } \\
\text { Generated Energy }\end{array}$ \\
\hline \multirow{11}{*}{ ڤ } & water & $\begin{array}{l}\text { evaporation, melting of ice } \\
\text { and snow, precipitation }\end{array}$ & water power plants & electricity \\
\hline & \multirow[t]{2}{*}{ wind } & atmospheric currents & wind farms & $\begin{array}{l}\text { thermal energy and } \\
\text { electricity }\end{array}$ \\
\hline & & energy of waves & wave power plants & electricity \\
\hline & \multirow{6}{*}{ solar radiation } & ocean currents & $\begin{array}{l}\text { ocean current energy } \\
\text { plants }\end{array}$ & electricity \\
\hline & & \multirow{2}{*}{$\begin{array}{l}\text { heating atmosphere and } \\
\text { Earth's surface }\end{array}$} & $\begin{array}{l}\text { ocean thermal energy } \\
\text { plants }\end{array}$ & electricity \\
\hline & & & heat pumps & thermal energy \\
\hline & & \multirow{3}{*}{ solar radiation } & $\begin{array}{l}\text { collectors and thermal } \\
\text { solar plants }\end{array}$ & thermal energy \\
\hline & & & $\begin{array}{l}\text { PV cells and solar power } \\
\text { plants }\end{array}$ & electricity \\
\hline & & & photolysis & fuels \\
\hline & \multirow[t]{2}{*}{ biomass } & \multirow[t]{2}{*}{ biomass production } & $\begin{array}{l}\text { heating and thermal } \\
\text { power plants }\end{array}$ & $\begin{array}{l}\text { thermal energy and } \\
\text { electricity }\end{array}$ \\
\hline & & & conversion devices & fuels \\
\hline 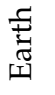 & radioactive decay & geothermal sources & $\begin{array}{l}\text { heating and geothermal } \\
\text { power plants }\end{array}$ & $\begin{array}{l}\text { thermal energy and } \\
\text { electricity }\end{array}$ \\
\hline $\begin{array}{l}5 \\
8 \\
\Sigma_{\Sigma}\end{array}$ & gravity & tidal moves & tidal power plants & electricity \\
\hline
\end{tabular}

Source: developed by the authors, based on Reference [26].

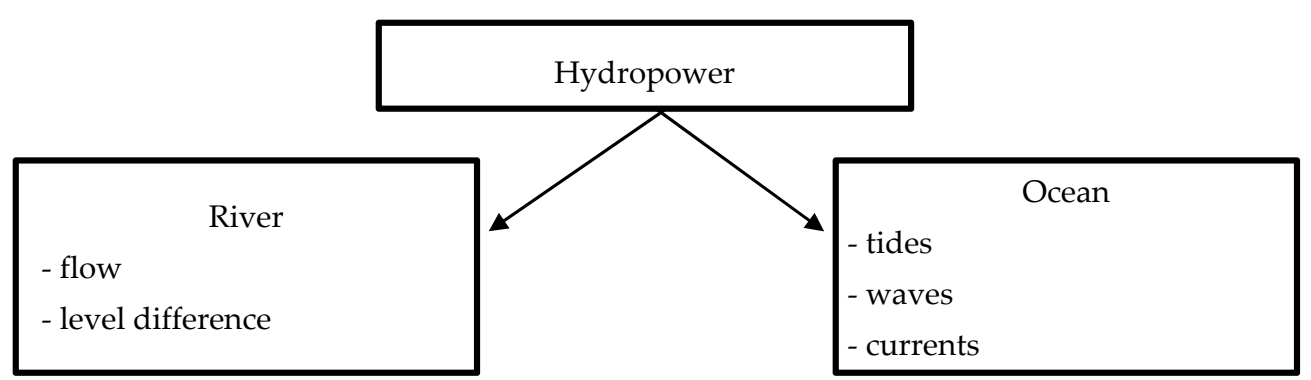

Figure 2. Classification of hydropower Source: developed by the authors, based on Reference [26].

The literature on renewable energy distinguishes two fundamental types of hydropower stations: impoundment and diversion ones. The former type has a reservoir, where water is collected and stored. In this type of hydro-electric station, electricity can be produced at any time. The other type does not have a water reservoir. Such hydropower stations are built in lowland areas. The amount of generated electricity is regulated through the natural power of flowing water. Other frequent types of power stations are:

- Cascading

- Small reservoir stations

- Impoundment facilities with large reservoir

- Diversion stations with no reservoir

- Pumped storage stations [26] 
The largest hydropower station in Poland is a pumped storage plant called Żarnowiec in Czyrmanów on Żarnowieckie Lake. It was built in 1983 with the installed capacity of 716 MW. The plant is fully automated and all the activities activating and deactivating the hydro-units are controlled remotely [39]. The greatest benefits of hydropower are saving of other natural resources, decrease in the use of conventional sources of energy (decrease in atmospheric pollutants harmful to the environment), lower cost of power generation, advanced automation of electricity production, and constant access to the water source. On the other hand, the greatest drawback of hydropower is interference with the natural environment, e.g., silting of riverbeds or alteration of landscape. Besides, large impoundment facilities may be conducive to the appearance of hazardous compounds, like methane. Other disadvantages are the high cost of construction and the level of noise [40].

Waves on the surface of seas and oceans are caused by wind, the Moon, and the atmospheric pressure. The energy generated by waves has been used by people in wave power stations. This was induced by the energy crisis in 1973. Ever since then, scientists have researched and designed projects exploiting wave energy. The three most important types of such power stations are pneumatic, attenuators, and point absorbers. Despite a large potential of sea waves, the power stations are not economical and cannot satisfy the need for energy security. On top of that, the amount of power they generate cannot be foreseen with any precision. Such power stations are used to supply energy to power sea installations, like signal buoys [41].

Wind is the moving mass of air, whose movement results from differences in atmospheric pressure. It flows from the areas of higher to lower pressure. Wind energy is connected with solar energy. Apart from solar radiation, the direction and strength of wind is determined by sea tides and the rotational movement of the Earth [26]. Wind generates mechanical energy, which is then converted to electricity. A great advantage of the potential of wind as an energy source is its availability in every location in the world. However, the location of a wind farm may be more or less effective, which depends on the topography of the location. Wind turbines will be more effective in plain or coastal areas [42]. In Poland, the best conditions for wind farms are in Pomerania and in the north-eastern part of the Suwałki region. Besides land wind farms, there are also off-shore wind farms, the first of which was constructed in Denmark. The construction cost of such wind farms is $50 \%$ higher than of those inland. This is offset by better wind parameters, and more coherence and predictability of wind in comparison to inland farms [26].

One of the most popular forms of RES is solar radiation, which is a basic energy source. People use it to produce thermal energy and electricity. It is present in every part of the world and is easily accessible. It is environmentally friendly, as no harmful substances are emitted to damage the natural world. The main problem of solar farms is the limited ability to store energy. The amount of generated power depends on the number end efficiency of the devices, state of the air, and the helioenergetic conditions [43]. Solar energy is exploited through three conversion mechanisms:

- Photovoltaic-electric

- Photothermal-thermal

- Photobiochemical—chemical bonds

Electricity is produced in photovoltaic cells, which are the smallest element of a solar panel. The more cells there are, the greater the capacity of the panel. At present, photovoltaic cells are used to illuminate houses and streets and to provide electricity where the access to a grid is not possible. They also power calculators, watches, meteorological stations, etc. Solar collectors are used to produce biomass, biogas, methanol, and rapeseed oil. In Poland, more and more photovoltaic devices are installed in more and more households as a source of heat and electricity. However, the helioenergetic conditions in Poland are not sufficient to satisfy energy demand [43]. The advantages of solar energy are:

- Wide availability of the energy source

- No cost of power consumption (after return on investment) 
- Environmentally friendly (no emissions of harmful substances)

- No impact on earth's energy balance (does not exhaust itself)

The drawbacks of this type of energy are:

- High cost of installation

- Seasonality (the generated power depends on the weather conditions, time of day, and season)

- Problems with storing the energy

- $\quad$ Requires a large area for installation [26]

Biomass is believed to be the least capital intense and the most promising source of renewable energy in the energy mix. The relevant literature furnishes many definitions of biomass: to quote the amended law on renewable energy of 7 June 2018, biomass is understood as "biodegradable parts of products, waste, and biological remains of agriculture, including vegetable and animal substances, forestry, and related industries, including fishery and acquaculture, as well as processed biomass, in particular in the form of pellets, briquette, biochar, and biocoal, and biodegradable parts of industrial waste or communal waste of vegetable or animal origin, including waste from recycling installations and waste from water and sewage treatment, in particular sewage sludge, in accordance with provisions on waste related to the qualification of energy recycled from thermal waste processing" [44]. Biomass can take three forms:

- Solid, e.g., wood

- Gaseous, e.g., biogas

- $\quad$ Liquid, e.g., bio-oil [45]

Solid biofuels are organic substances, currently used in the energy industry as fuel to produce electricity and thermal energy. Biofuels include firewood, sawdust, wood chips, grasses, grains, charcoal, agricultural, horticultural waste, and waste from the furniture industry. The process of biomass fermentation produces biogas. It is a flammable gas, mostly composed of methanol and carbon dioxide. The type of biogas depends on the origin of the fermented waste. The most frequently used waste for producing biogas comes from vegetable and animal waste, landfills, sewage sludge, breweries, slaughterhouses, and other food-processing plants. Liquid biofuel used in transport is also produced from plants, i.e., grains, potatoes, beetroots, energy crops, etc. The biofuel generated through conversion processes may also serve as substitutes or additions to petrol and diesel oil. Biofuels include bio-liquids, which are used in the production of electricity and thermal energy [43]. The greatest advantages of using biomass in the energy industry are:

- Economic activation of rural communities

- Creating additional jobs

- Constant access to sources and media of energy

- Use of the overproduced food

- Use of the generated waste

- Developing wastelands

- Increase in energy security

On the other hand, the disadvantages of biomass are:

- Risk of decreasing the biodiversity of crops

- Increase in atmospheric pollution from biomass combustion

- Toxic and carcinogenic emissions from pesticide-contaminated biomass combustion

- Smaller power generation capacity in comparison to fossil fuels

- Seasonality of some plants [26] 
Another RES is geothermal energy, which occurs as a result of the difference in temperatures between the Earth's inside and its surface. The temperature in the inner core of the Earth reaches $6000{ }^{\circ} \mathrm{C}$, while dropping to $15^{\circ} \mathrm{C}$ on the surface. Such a vast difference in temperature values drives the constant flow of heat from the inside of the Earth to its surface. At present, this type of energy is used to produce electricity and directly as a source of heat. The advantage of geothermal sources over other renewable media of energy is that geothermal energy is supplied on a regular basis, independent of external factors, like the weather [25]. Geothermal sources have a wide range of applications: besides electricity and heat generation, they can be utilized in tourism, health resorts, animal husbandry, fruit drying, and heat pumps. Geothermal power generation has been developing rapidly in many countries.

The greatest benefits of this type of energy are the local character of the energy resources (opportunity of extraction at the point of use), independence of the weather, and no negative impact on the natural environment. The most important drawbacks are the risk of water and atmosphere contamination, and accessibility. Even though Poland does not lie in a seismic area, it has very good geothermal conditions. The first geothermal heating plant in Poland was established in the village of Bańska Niżna in Lesser Poland in 1993. The heating plant has the capacity of $41 \mathrm{MWt}$ and produces heating and commercial thermal energy. The plant uses the energy from thermal water, which is extracted from three wells. Next, the geothermal water is transferred through a pipeline to heat converters, where it warms up the network water. Finally, the geothermal water is sent back to the well through absorbent holes [46].

The review of the energy sources presented above suggests many opportunities of generating energy. The selection of a source is determined by the geographic location, climate conditions, owned technology, public awareness and economic situation of the country. Poland, owing to its geological conditions, has a potential to increase the use of RES. These types of energy could have a larger share in the overall energy mix when the financing of the RES sector and public awareness are raised to a satisfactory level.

\subsection{Prospects for Development of Renewable Energy Sources in Poland}

The introduction of the Energy Law Act of 1997 in Poland gave rise to many legal regulations which encouraged the investment into non-conventional energy sources [38]. A financial support scheme was designed to encourage entrepreneurs to commit to a greater use of RES and consequently, to improve the country's chance of meeting the long-term EU targets set by the Directive of the European Parliament and Council of 2009. The directive assumed that the share of RES in Poland should reach $15 \%$ of the overall energy consumption by 2020 .

Annual publications of the Ministry of Energy showed in 2016 that the share of the energy generated from renewable sources reached $13.53 \%$ in the total energy consumption. This fell short of the intended target by $0.32 \%$, thus implicating a slowdown in the development of the renewable energy in Poland, which may have been caused by the amendments to the law on renewable energy and in the system of public support. Thus, Poland will not be able to increase the share of non-conventional resources in the total energy consumption even to the minimum level of $15 \%$ in 2020 . The increase of this share in the fuel and energy mix will require large financial investment. However, in the long-term, this process will be profitable, as it will enable the state to avoid paying penalties for breaking EU norms, to reduce the coal extraction cost, and to expand the number of installations [47]. Besides, the increase in the consumption of renewable energy will improve the condition of the natural environment and raise the quality of life.

Every country strives to raise the competitiveness of its economy. This objective can be met through innovative solutions which facilitate progress in various industries, like the energy sector. Poland was pursuing this goal when the Ministry of Energy presented their document Poland's Energy Policy until 2040. The document is an action plan and set the objectives for various sectors of the 
energy industry, where the government should seek modernization. It was assumed that Poland should concentrate on:

- Increasing energy security

- Increasing economic effectiveness

- Reducing negative impacts on the environment

- Limiting $\mathrm{CO}_{2}$ emissions

- Expanding the financing of RES, which will lead to its development and creation of new jobs [13]

The measures envisaged by the PEP (Poland's Energy Policy) strategy which concern solely the non-conventional sources of energy should concentrate on the following areas:

- Electrical power engineering

- Transport

- Heating and cooling

In the first area, progress will not start in earnest until 2025. The share of green energy will remain at the same level until new mechanisms are introduced to support the development of the infrastructure conducive to the development of renewable energy. This aim will be achieved through photovoltaic, progress in electricity from offshore wind farms, progress in bioenergy from vegetable waste and biogas and, to the smallest extent, the development in hydro-energy from hydroelectric power stations. In the second area, i.e., transport, the growth of renewable energy will require large investment. As electric engine cars will become more popular, the network of EV charging stations will need to be expanded. The plan also envisages the expansion of biofuel production. The next step will involve benefits and incentives for EV purchases and financial reliefs for low-emission transport. In the area of heating, the largest developments are foreseen in biomass and biogas, as Poland has a good availability of resources and a significant production capacity in this field. On top of this, geothermal and solar energy will become more prominent, particularly in locations with good insolation [13].

The following projects will contribute to the development of the RE in Poland:

- Offshore wind energy (new wind farms of projected capacity up to $14 \mathrm{GW}$ )

- Production of energy for own needs:

- Energy clusters (dealing with the local energy security and independence)

- Energy cooperatives (producing energy for own needs and selling the surplus on to the national system, e.g., "New Energy")

- $\quad$ Prosumers (producers and consumers in one person) [13]

\subsection{Renewable Energy Sources in Light of Own Research}

\subsubsection{Characteristics of Respondents}

The survey was conducted online in August 2019. It involved 236 participants aged between 19 and 67 , with a slight majority of men (119 participants, 50.42\%) over women $(117,49.58 \%)$. The largest group of participants was aged $46-50$ (34.32\%), then 36-45 (29.24\%), 19-25 (19.49\%), and 25-35 (11.86\%). The smallest number of participants, 5.08\%, were people aged over 60 years. As Figure 3 shows, over $85 \%$ of the respondents were city residents, while the other $15 \%$ lived in rural areas. Most of the respondents, 119 participants $(50.42 \%)$, declared living in a city of over 500,000. The smallest number of respondents, $24(10.17 \%)$, lived in towns of under 50,000 inhabitants. 


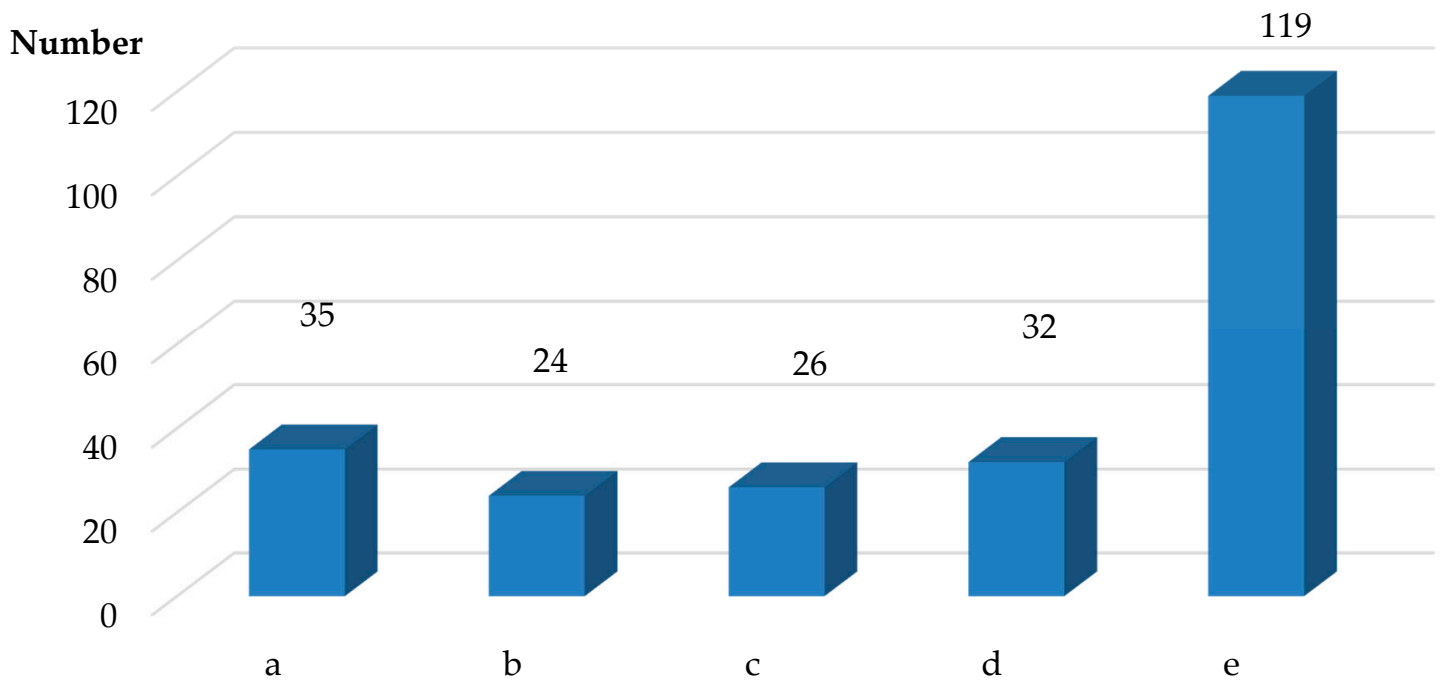

Figure 3. Place of residence, a-village residents, b-city under 50,000, c-city 50,000-150,000, d-city 150,000-500,000, e-city over 500,000. Source: developed by the authors, based on own research.

The largest number of respondents (50 participants, $21.19 \%$ ) declared net monthly income in the household of over 3000 EUR. The second largest group, 30 participants $(12.71 \%)$, was in the 1001-1150 EUR bracket, followed by 29 participants (12.29\%) in the EUR 401-750range. The fewest respondents-16 participants (6.78\%), declared their income to be between EUR 200 and 400 (Figure 4).

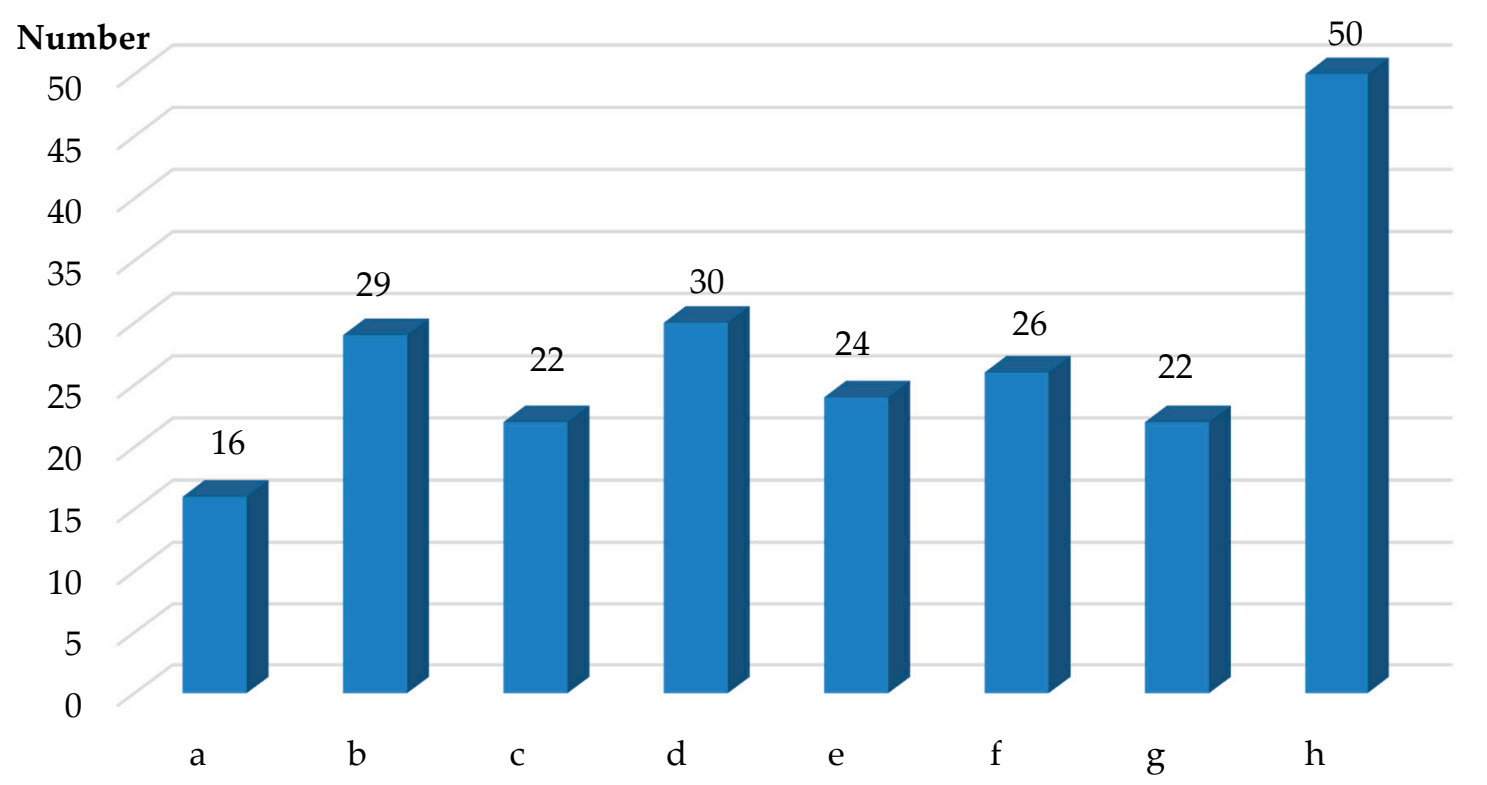

Figure 4. Average monthly net income in the household. a-EUR 200 to 400, b-EUR 401 to 750, c-EUR 751 to 1000, d-EUR 1001 to 1150, e-EUR 1151 to 1500, f-EUR 1501 to 2000, g-EUR 2001 to 3000, h-over EUR 3000. Source: developed by the authors, based on own research.

\subsubsection{State of Knowledge of the Renewable Energy Sources Dents}

An overwhelming majority of the respondents (233 people, $98.73 \%$ ) declared knowing the term renewable energy sources. Only 2 respondents had never heard this term. Nearly all of them supported the development of renewable energy sources $(97.5 \%)$, and 6 respondents $(2.5 \%)$ did not offer an opinion in this matter. 
The respondents were asked to define renewable sources of energy. Most of them, 208 (99.14\%), knew the definition, 6 participants (2.54\%) admitted they did not, and 22 of the subjects $(9.32 \%)$ did not have an opinion.

Only 24 respondents $(10.14 \%)$ declared that their knowledge of renewable energy sources was very good, and 75 participants (31.78\%) as good. The largest number, 121 (51.27\%) evaluated their knowledge as average. The smallest number, 16 participants $(6.78 \%)$, said their knowledge of the subject was poor.

The survey respondents were also asked what sources of renewable energy they have personally encountered. The largest number of 205 subjects $(86.86 \%)$ pointed at solar energy collectors, 195 respondents $(82.63 \%)$ marked wind farms, and $158(66.95 \%)$ of the participants indicated hydroelectric stations. The smallest number of the respondents $(18.64 \%)$ had seen biogas stations, biomass power plants (19.92\%), and tidal and wave energy stations (19.07\%) (Figure 5).

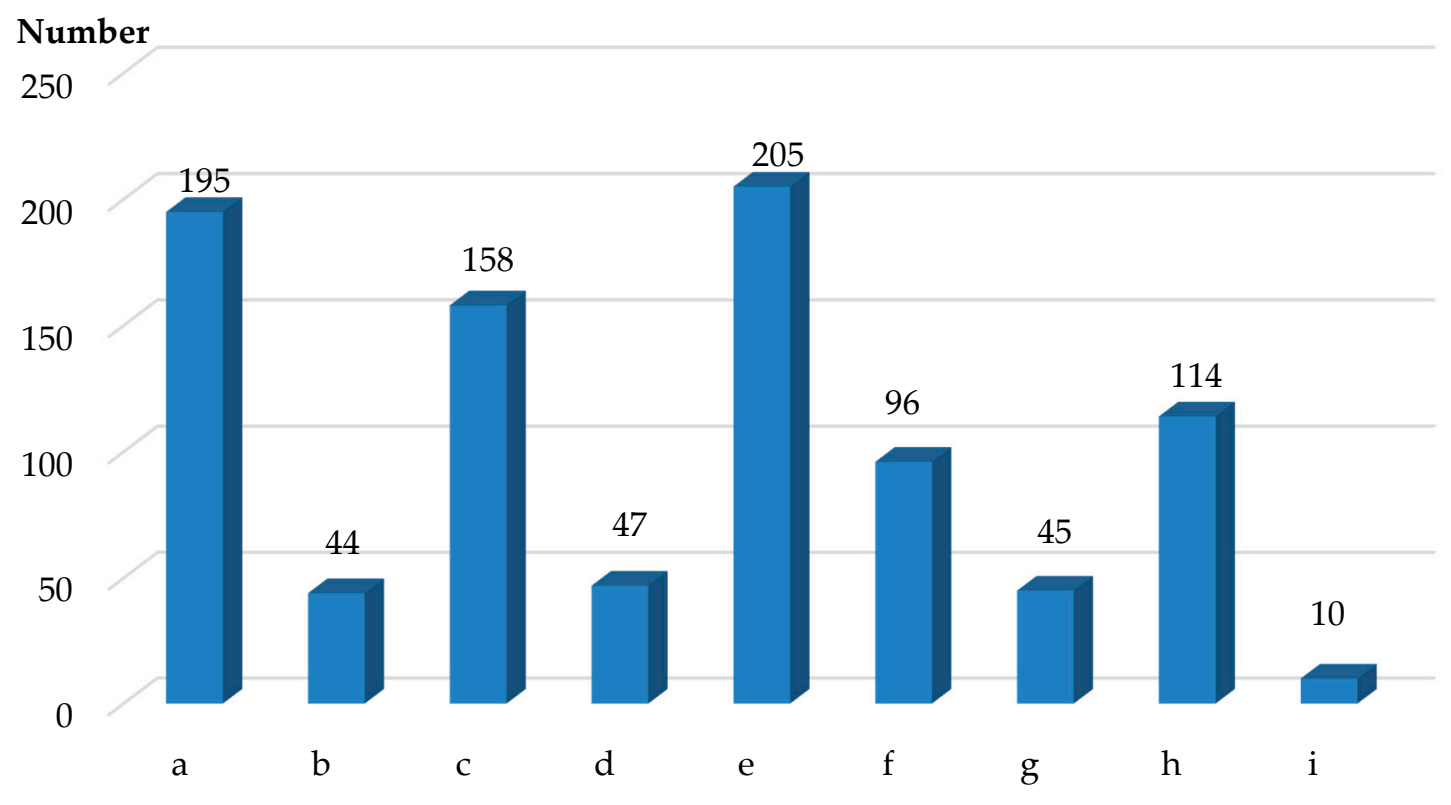

Figure 5. Contact with types of renewable energy. Respondents could select more than one answer. a-wind farms, b-biogas power plants, c-hydroelectric stations, d-biomass energy plants, e-solar collectors, f-geothermal devices, g-tidal and wave energy stations, h-biofuels, i-never met. Source: developed by the authors, based on own research.

Over half of the respondents, 124 (52.54\%), had never used renewable energy sources, 82 (34.75\%) subjects said they had used them, and $30(12.71 \%)$ said they could not answer.

The respondents were asked to assess which sources of energy had the best potential of development. The largest number, $177(75 \%)$, chose solar energy, $140(59.32 \%)$ wind energy, $78(33.05 \%)$ nuclear power, and 77 (32.63\%) hydro-energy. The fewest of the respondents, $25(10.95 \%)$, selected primary energy (Figure 6).

Of the respondents, $169(71.61 \%)$ maintained that solar energy was the most eco-friendly, followed by wind farms $(152$, or $64.41 \%)$ and hydropower $(117$, or $49.58 \%)$. The smallest number of the participants pointed at biomass (33, or $13.98 \%)$, nuclear power $(29$, or $12.29 \%)$, and primary energy (28, or $11.86 \%)$.

In another entry, the respondents answered which energy source, in their view, dominated in Poland (Figure 7). Most of them chose wind energy -87 respondents, or $36.86 \%$, followed by primary energy $(59$, or $25.0 \%)$ and solar ( 42 , or $17.8 \%)$. Only 3 people chose geothermal energy $(1.27 \%)$ and only one person $(0.42 \%)$ selected biomass energy. 


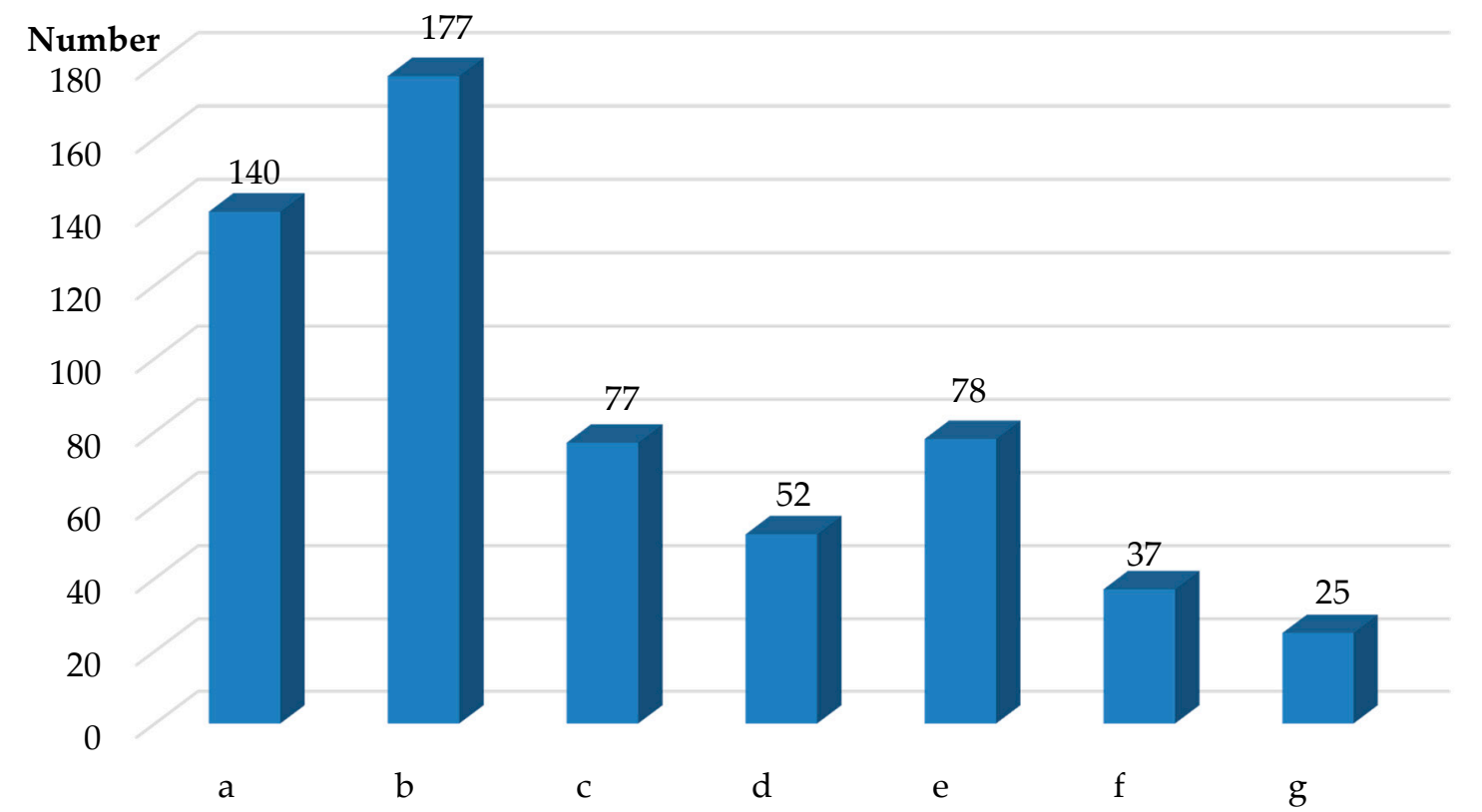

Figure 6. Assessment of development potential of energy type. Respondents could select more than one answer. a-wind, b-solar, c-hydro, d-geothermal, e-nuclear, f-biomass, g-primary energy. Source: developed by the authors, based on own research.

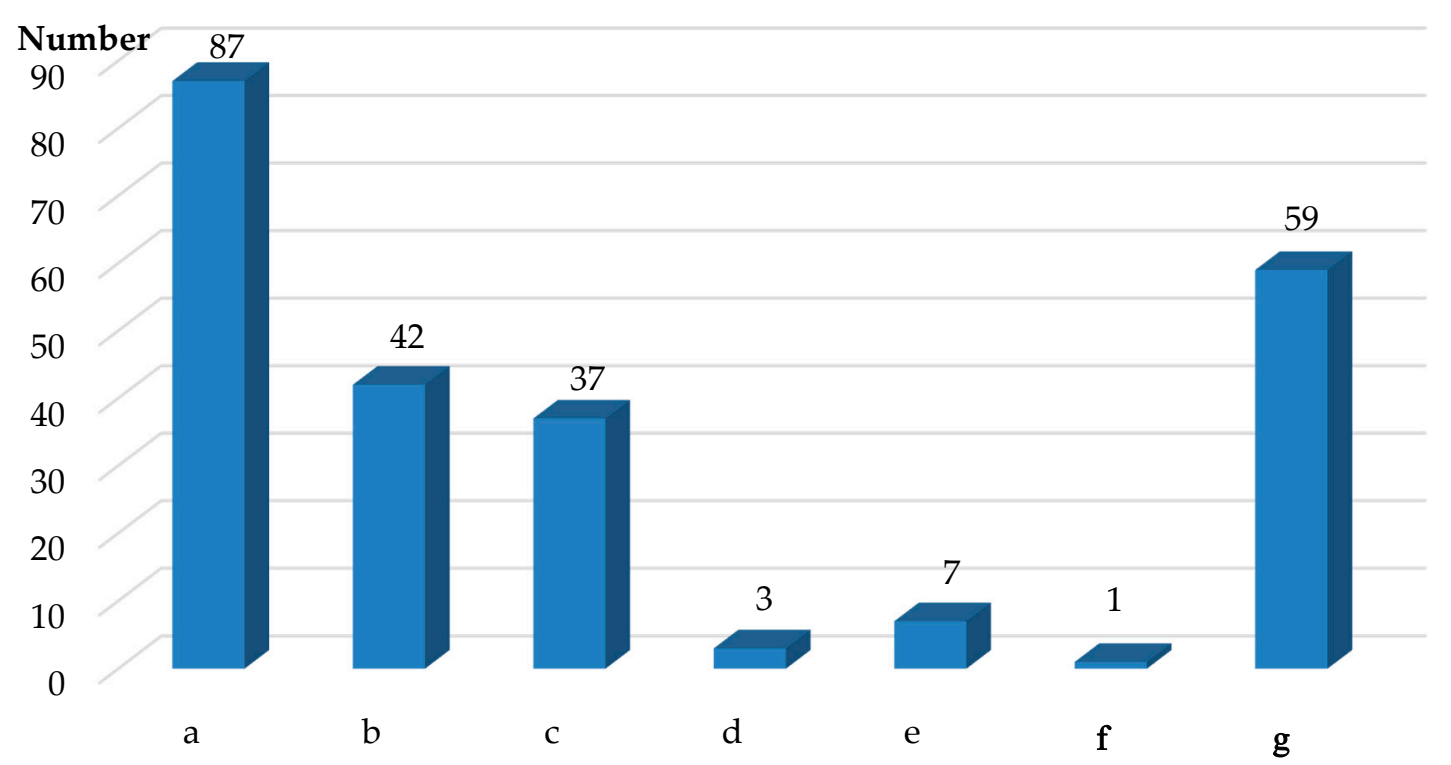

Figure 7. Dominant energy source in Poland. Respondents could select more than one answer. a-wind, b-solar, c-water, d-geothermal, e-nuclear, f-biomass, g-primary energy. Source: developed by the authors, based on own research.

Nearly half of the respondents, $114(48.31 \%)$, believed that renewable energy sources have the capacity to satisfy man's energy needs. Only 41 respondents $(17.37 \%)$ said this was impossible, and 81 $(34.32 \%)$ offered no view in this matter. On the basis of the relevant literature, it can be concluded that most scientists, quoting own research, believe that renewable energy is not able to replace conventional energy, but can only play a supplementary role. One of the problems is that no adequate storage technology has been invented yet to store the energy from renewable sources [48]. 
Less than half of the respondents, $101(42.80 \%)$, said they were ready to pay a higher price for the services relying on renewable energy, while 61 respondents $(25.85 \%)$ expressed the opposite view, and 74 (31.36) had no firm conviction about this.

In the view of 158 participants (66.95\%), the greatest disadvantages of using renewable energy are expensive installations and dependence on the climate and weather $(157$, or $66.53 \%)$. Another drawback indicated in the survey was insufficient production capacity (77 subjects, or $32.63 \%$ ) and interference with the landscape $(71$, or $30.08 \%)$. A few respondents (10, or $4.24 \%)$ selected the answer "other" and presented their own suggestions of the RES shortcomings (Figure 8). The most important of these were: unreliable power generation, lack of consistency, necessity to transfer energy over long distances, tight connection of a power plant with the location (which meets specific conditions), lack of storage capacity to store the produced energy, the market for green certificates and its anomalies, which hinder the development of this type of energy, while the new technologies are so expensive that they cannot be a feasible alternative without "subsidies".

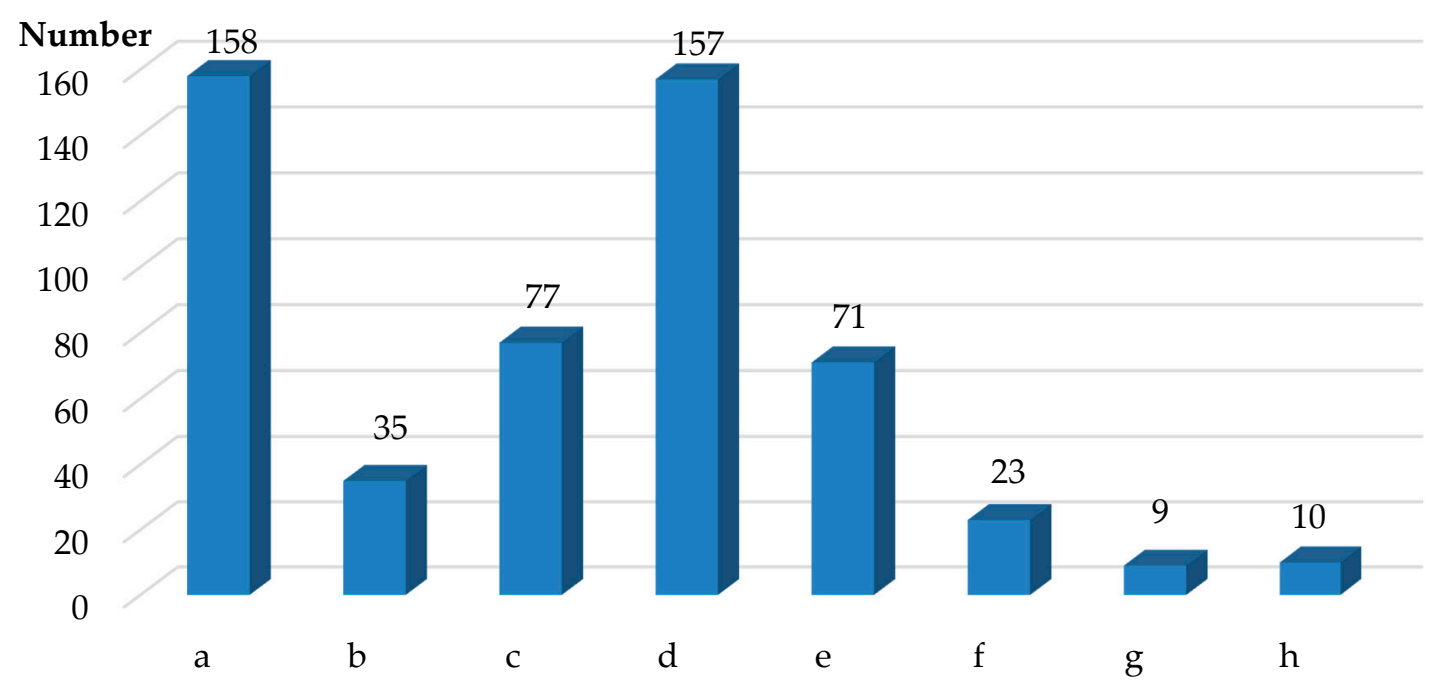

Figure 8. Assessment of the greatest disadvantages of renewable energy. Respondents could select more than one answer. a-expensive installations, b - technical problems in use of devices, c - too little energy capacity, $\mathrm{d}$-dependence on climate and weather, e-interferences with landscape (e.g., raising wind farms on farm land or flooding areas for reservoirs for hydroelectric stations), f-turbine noise, $\mathrm{g}$-interferences with radio and TV signal, $\mathrm{h}$-other. Source: developed by the authors, based on own research.

In the next questionnaire entry, the respondents were asked to choose the greatest benefits of renewable sources of energy. Most of them (196, or $83.05 \%$ ) chose the reduction in air pollution and the care of the natural environment (165, or $69.92 \%)$. Less than half of the subjects chose the infinity of energy resources (100, or $42.37 \%$ ) and the decrease in the use of fossil fuels (97, or 41.10\%) (Figure 9).

The respondents were asked about the factors which could contribute to the increase in the share of renewable energy in the energy mix. They decided that the optimal contribution would be financial incentives for investment in RES-187 (79.24\%), and tax reliefs-159 (67.37\%) (Figure 10). Some respondents (8, or 3.39\%) selected "other" and pointed at: clear legal regulations, unambiguous executive regulations, possibility to sell energy back to the grid, common European energy market-tighter cooperation and better trans-border flows, the government investment in nuclear power, and complex projects for construction of small and micro-power plants. 


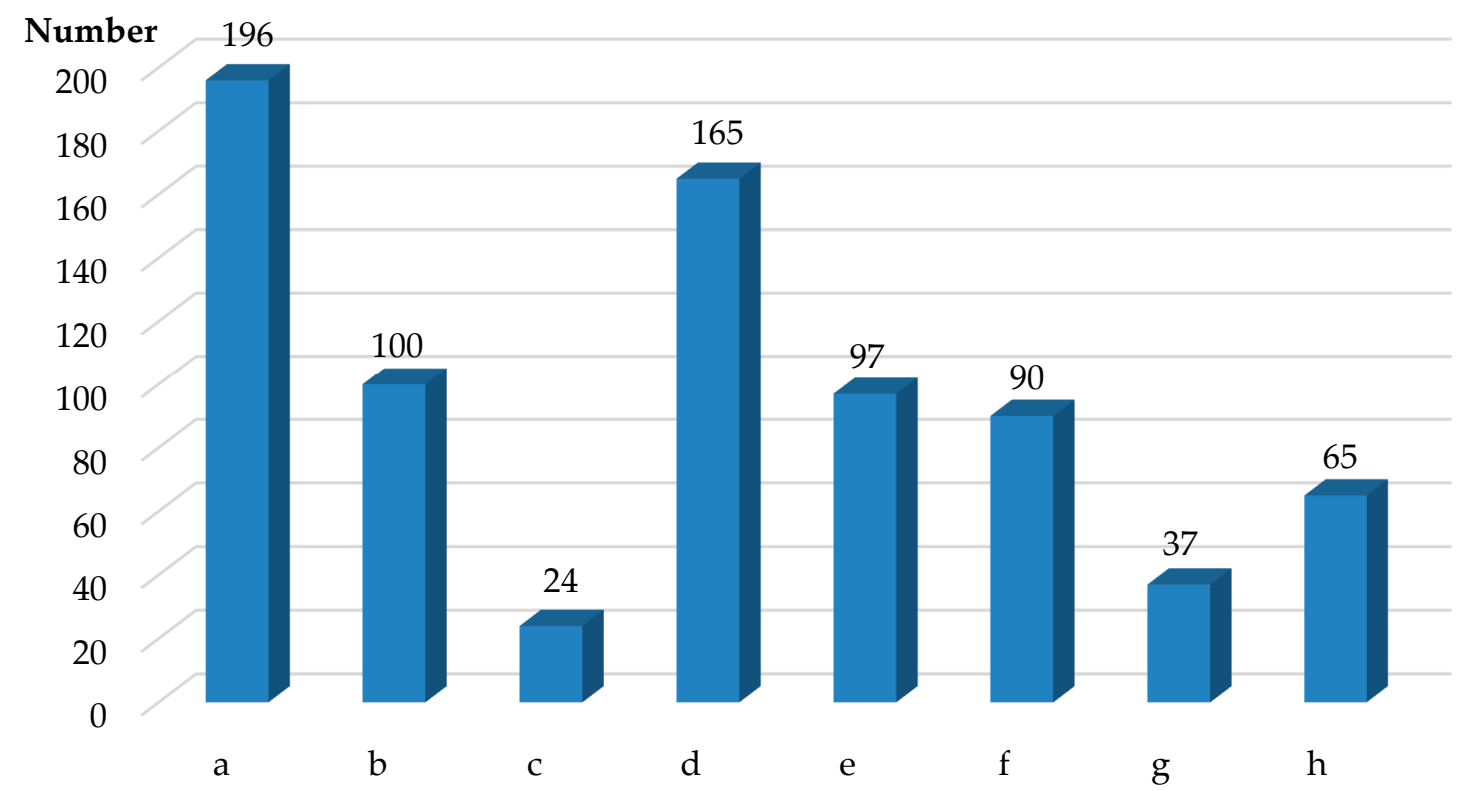

Figure 9. Assessment of greatest benefits of renewable energy resources. Respondents could select more than one answer. a-reduction in air pollution, b-infinity of energy resource, c-man-made reservoirs limit the risk of floods, $\mathrm{d}$-care of the natural environment, $\mathrm{e}$-reduction in the use of fossil fuels, f-use of free energy (e.g., solar, wind, and hydro), g-self-regulation of energy resources, $\mathrm{h}$-economic benefits. Source: developed by the authors, based on own research.

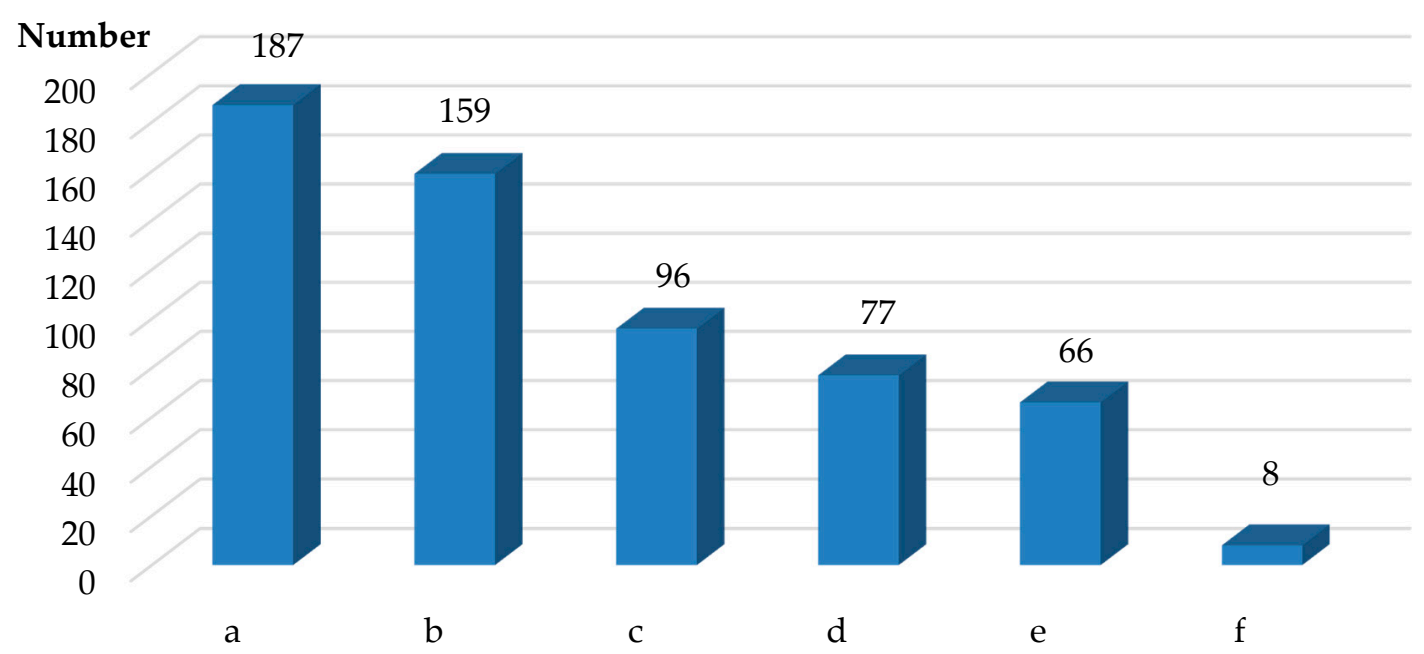

Figure 10. Factors contributing to the increase in the share of renewable energy in the energy mix. Source: developed by the authors, based on own research. Respondents could select more than one answer. a-subsidies for investment in renewable energy, b-tax reliefs, c-care of the climate and environment, $\mathrm{d}$-increased energy independence, $\mathrm{e}$ - exhaustion of non-renewable energy resources, $\mathrm{f}$-other.

In light of a dramatic decline in the quality of air and increasingly frequent weather anomalies around the planet, every country should make it a priority to limit the use of conventional energy and replace it, to the largest possible extent, with renewable energy resources. Primary energy still dominates in Poland's energy mix. Apart from the deteriorating climatic conditions, Poland as an EU member state is under obligation to implement such changes in accordance with the ratified agreements concerning the protection of the environment and energy security. 


\subsubsection{Analysis of the Energy Mix}

The present chapter investigated Poland's energy mix. The considerations are based on data supplied by Statistics Poland. Following the definition found in the encyclopedia by Polish Scientific Publishers PWN, the energy mix is "a listing where the inward register includes the sum of energy fed into the studied system and the energy generated in this process, and the outward register includes the sum of useful and lost energy" [49]. Table 2 enumerates the total amount of the generated primary energy and the amount of energy from renewable resources in Poland, in comparison to the member states of the European Union. Years 2013-2016 witnessed a positive trend of the growing share of renewable resources in the total generated energy. This growth in Poland reached 1.5 percentage points, while in the EU it equaled 15.7 percentage points. In the analyzed period, overall generation of power in the EU decreased from 792.1 Mtoe in 2013 to 755.4 Mtoe in 2016; in Poland, this value dropped by 4.2 Mtoe in the same period.

Table 2. Generation of primary energy.

\begin{tabular}{ccccccccc}
\hline \multirow{2}{*}{ Countries } & $\mathbf{2 0 1 3}$ & $\mathbf{2 0 1 4}$ & $\mathbf{2 0 1 5}$ & $\mathbf{2 0 1 6}$ & $\mathbf{2 0 1 3}$ & $\mathbf{2 0 1 4}$ & $\mathbf{2 0 1 5}$ & $\mathbf{2 0 1 6}$ \\
\cline { 2 - 8 } & \multicolumn{7}{c}{ Generation of Primary Power } \\
\cline { 2 - 8 } & \multicolumn{7}{c}{ Total (Mtoe) } & \multicolumn{7}{c}{ from Renewable Sources (Mtoe) } \\
\hline Poland & 70.6 & 66.9 & 67.6 & 66.4 & 8.5 & 8.1 & 8.8 & 9.0 \\
EU-28 & 792.1 & 774 & 767.4 & 755.4 & 195 & 197.9 & 205.8 & 210.7 \\
\hline
\end{tabular}

Source: developed by the authors, based on Reference [50]. EU, European Union.

In the years 2013-2017, the total of the generated primary energy was at a similar level, with small fluctuations. It peaked in 2013, at 3,006,461 TJ. In further analysis, we observed a positive trend of the increasing share of renewable sources in the general energy mix: this value went up from $11.9 \%$ in 2013 to $14.1 \%$ in 2017. This followed from the increase in the generation of power from renewable sources by nearly 7\% in 2017 against year 2013 (Table 3).

Table 3. Generation of primary energy, including energy from renewable sources.

\begin{tabular}{cccccc}
\hline Specification & $\mathbf{2 0 1 3}$ & $\mathbf{2 0 1 4}$ & $\mathbf{2 0 1 5}$ & $\mathbf{2 0 1 6}$ & $\mathbf{2 0 1 7}$ \\
\hline $\begin{array}{c}\text { (TJ) } \\
\text { Total generation of primary energy }\end{array}$ & $3,006,461$ & $2,853,825$ & $2,869,751$ & $2,804,263$ & $2,722,815$ \\
$\begin{array}{c}\text { Generation of primary energy from } \\
\text { renewable sources }\end{array}$ & 358,343 & 339,835 & 372,050 & 380,134 & 383,168 \\
$\begin{array}{c}\text { Share of renewable energy in the total } \\
\text { generation }\end{array}$ & 11.9 & 11.9 & 13 & 13.6 & 14.1 \\
\hline & Source: own elaboration based on Reference [51].
\end{tabular}

In 2018, the largest amount of renewable energy in Poland was generated from solid biofuels-252,821 TJ (68.88\%), followed by wind energy-46,076 TJ $(12.55 \%)$ and liquid biofuels-37,920 TJ (10.33\%). The smallest share in the energy produced from renewable sources was composed of geothermal energy—991 $\mathrm{T}(0.27 \%)$, heat pumps—-2498 TJ $(0.68 \%)$, and solar power-3465 TJ (0.94\%) (Figure 11).

In 2013-2015, Poland used more solid biofuels for energy production than the EU average. The situation was reversed in 2016. The consumption level of solar, hydro, and geothermal energy and biodegradable communal waste in Poland is significantly lower than in EU countries. The opposite situation was noticed in the case of liquid biofuels (Table 4). 


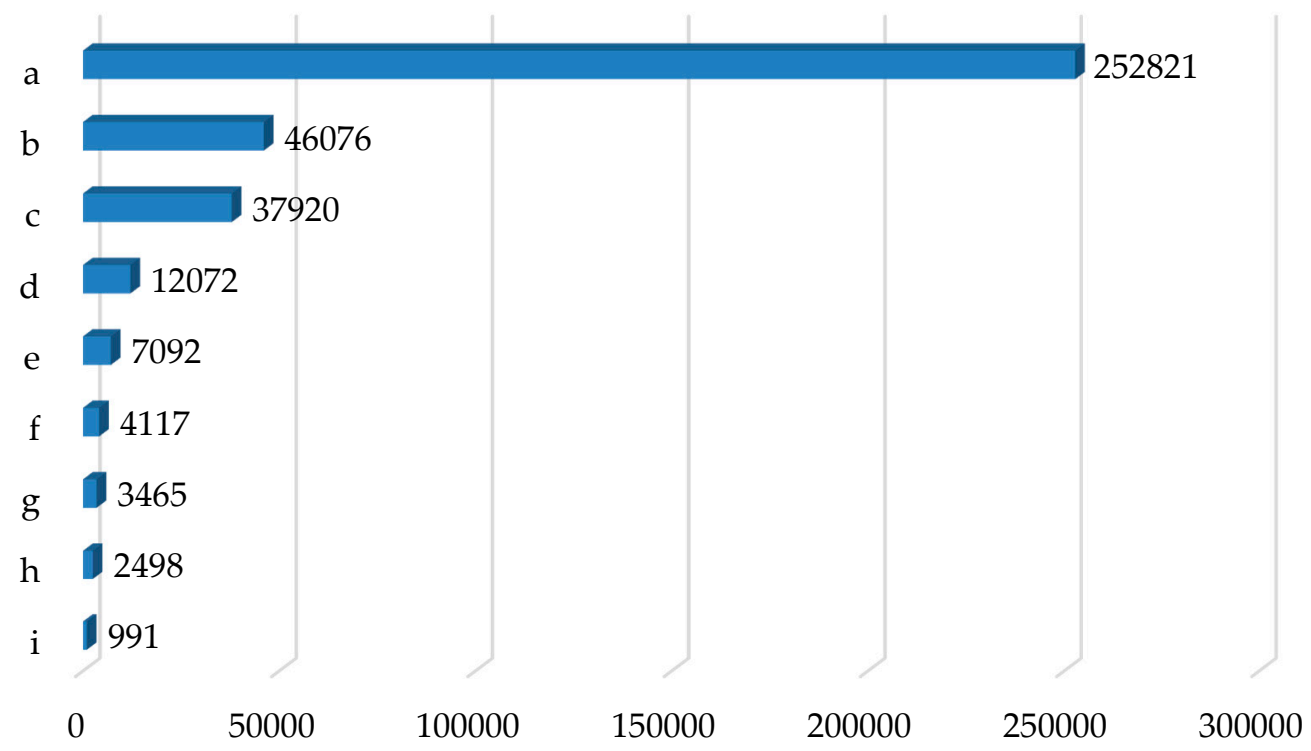

Figure 11. Generation of power from renewable sources in Poland in 2018 by the media (TJ). a—solid biofuels, $\mathrm{b}$ —-wind energy, c-liquid biofuels, $\mathrm{d}$-biogas, e-hydro-energy, $\mathrm{f}$-communal waste, g-solar power, h-heat pumps, i-geothermal energy. Source: developed by the authors, based on Reference [51].

Table 4. Structure of energy generated from renewable sources by sources for Poland and EU-28 (\%).

\begin{tabular}{cccccc}
\hline Source & & $\mathbf{2 0 1 3}$ & $\mathbf{2 0 1 4}$ & $\mathbf{2 0 1 5}$ & $\mathbf{2 0 1 6}$ \\
\hline \multirow{2}{*}{ Solid biofuels } & Poland & 80.2 & 76.6 & 74.6 & 71.1 \\
& EU-28 & 46.3 & 44.1 & 44.6 & 77.7 \\
\hline \multirow{2}{*}{ Solar power } & Poland & 0.3 & 0.4 & 0.6 & 0.7 \\
& EU-28 & 5.5 & 6.1 & 6.3 & 6.3 \\
\hline \multirow{2}{*}{ Hydro-energy } & Poland & 2.5 & 2.3 & 1.8 & 2.0 \\
& EU-28 & 16.4 & 16.3 & 14.3 & 14.3 \\
\hline \multirow{2}{*}{ Wind energy } & Poland & 6.1 & 8.2 & 10.6 & 12.0 \\
& EU-28 & 10.4 & 11.0 & 12.6 & 12.4 \\
\hline \multirow{2}{*}{ Biogas } & Poland & 2.1 & 2.6 & 2.6 & 2.9 \\
& EU-28 & 7.2 & 7.6 & 7.7 & 7.9 \\
\hline \multirow{2}{*}{ Liquid biofuels } & Poland & 8.2 & 9.2 & 9.2 & 10.2 \\
& EU-28 & 6.5 & 7.1 & 6.6 & 6.5 \\
\hline \multirow{2}{*}{ Geothermal energy } & Poland & 0.2 & 0.3 & 0.2 & 0.2 \\
& EU-28 & 3.0 & 3.1 & 3.1 & 3.2 \\
\hline Biodegradable & Poland & 0.4 & 0.5 & 0.5 & 0.9 \\
communal waste & EU-28 & 4.6 & 4.7 & 4.7 & 4.7 \\
\hline
\end{tabular}

Source: developed by the authors, based on Reference [50].

Years 2014-2018 in Poland witnessed a positive tendency of the increasing share of renewable sources in the total gross energy consumption. In 2014, that value stood at 309,100 TJ, while in 2018, it reached $349,793 \mathrm{TJ}$, a growth of $13.6 \%$. The largest year on year increase in that period occurred in 2018-11,773 TJ (Figure 12). 


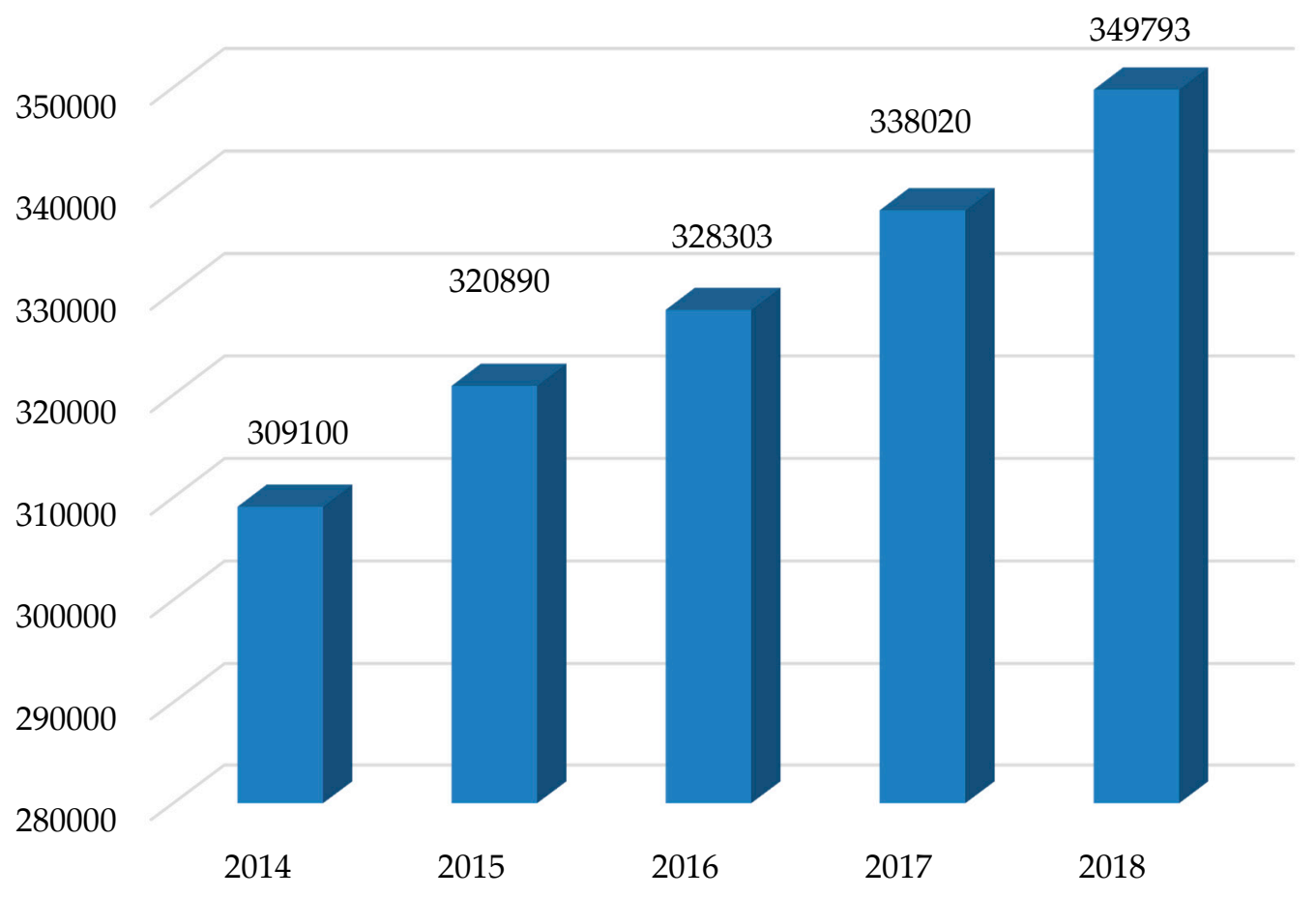

Figure 12. Total gross energy consumption from renewable sources in years 2014-2018 (TJ). Source: developed by the authors, based on Reference [51].

In recent years, the ratio of renewable sources of energy in Poland's energy mix has been constantly growing. This is a positive trend, although the degree to which these resources are exploited is still too low, and lower than in most EU countries. As fossil fuels are becoming exhausted and the state of the natural environment is declining, Poland should focus on making the most of its renewable energy resources.

\section{Conclusions}

Renewable sources of energy will become more and more prominent in the global energy generation in the coming years. This follows from the declining state of the natural environment and the growing energy intensity of many industries. Higher consumption of energy is also driven by the global population growth and the need to provide decent living standards around the world.

The research objective was achieved with the use of answers collected via survey and elaborated in addition to some data obtained from Statistics Poland (GUS). The data-based conclusions were interpreted in the light of relevant scientific literature.

The survey results demonstrated that nearly all respondents who participated in the study declared the knowledge of the term renewable energy resources $(99.14 \%)$. The respondents have a diverse level of knowledge in the investigated area. A slight majority considered their state of knowledge to be average (51.27\%). This may follow from the fact that most survey participants do not use renewable energy resources and do not know any RES power plants in their locations. According to the respondents, the most popular RES facilities in Poland are solar power plants $(86.86 \%)$ and wind farms $(82.36 \%)$. The respondents maintained that photovoltaic facilities are the most environmentally friendly and have the best outlook for development.

Energy from solar and wind power can improve Poland's energy safety. However, taking into account the identified barriers (legal, financial, impact on the natural environment), the role of these sources of energy in Poland's energy mix must not be overestimated and any actions taken in this area should be preceded by comprehensive analysis. 
Although they appreciated the importance and benefits of renewable energy, the respondents claimed that these resources will not fully satisfy the demand for electricity, and that they would be unwilling to bear higher cost of using renewable energy. As they are aware of the growing air pollution, the respondents $(83.05 \%)$ pointed at the improvement in air quality as the greatest advantage of renewable energy resources. Despite many benefits of the use of renewable resources, the survey participants were discouraged by the high cost of installations and the dependence of RES power stations on the local and atmospheric conditions. The respondents expressed the view that the best encouragement for the increased share of the renewable resources in the energy mix would be expanded subsidies and tax reliefs.

The data collected by GUS (Central Statistical Office) show that energy from renewable resources has recently been increasing its share in Poland's ultimate energy mix (from 309,100 TJ in 2014 to 349,793 TJ in 2018). In 2018, most energy from renewable sources came from the use of solid biofuels $(252,821$ TJ). Despite the constant progress of the RES sector in Poland, their share in the energy mix is still far from being sufficient (14.1\% in 2017) to meet the norms adopted by the EU.

Poland's government institutions should prioritize measures leading to a greater use of non-conventional sources of energy. To this end, the action plan envisaged in Poland's energy policy until 2040 should be implemented. This will ensure Poland is not financially penalized for failing to meet the energy obligations set by the European Union in the future. The development of RES can also contribute to the improvement in air quality and creation of new jobs. An increase in the energy security of Poland will be the crowning achievement.

Author Contributions: Conceptualization, R.M.-B. and S.B.; methodology, R.M.-B. and S.B.; formal analysis, K.K. and K.P.; investigation, K.P., R.M.-B. and S.B.; data curation, S.B., K.K. and K.P.; writing-original draft preparation, R.M.-B., S.B., K.P. and K.K.; writing-review and editing, R.M.-B., S.B., K.K. and K.P.; supervision, R.M.-B.; project administration, S.B. All authors have read and agreed to the published version of the manuscript.

Funding: This research received no external funding.

Conflicts of Interest: The authors declare no conflict of interest.

\section{References}

1. Chen, W.-H.; Budzianowski, W.; Lee, K.T. Preface-Sustainable Biofuels. Energy Convers. Manag. 2017, $141,1$. [CrossRef]

2. Bhaskar, T.; Bhavya, B.; Singh, R.; Naik, D.V.; Kumar, A.; Goyal, H.B. Thermochemical conversion of biomass to biofuels. In Biofuels-Alternative Feedstocks and Conversion Processes; Pandey, A., Larroche, C., Ricke, S.C., Dussap, C.G., Gnansounou, E., Eds.; Academic Press: Oxford, UK, 2011; pp. 51-77. [CrossRef]

3. Rosales-Calderon, O.; Arantes, V. A review on commercial scale high value products that can be produced alongside cellulosic ethanol. Biotechnol. Biofuels 2019, 12, 240. [CrossRef]

4. Kościółek, M.; Ziółko, M. Udział energii odnawialnej w bilansie energetycznym województwa podkarpackiego (The share of renewable energy in the energy balance of the Podkarpackie Voivodeship). Humanit. Soc. Sci. 2015, 22, 79-89.

5. Escobar, J.A.; Lora, E.E.; Venturini, O.J.; Yánez, E.; Castillo, E.F.; Almazán, O. Biofuels: Environment, technology and food security. Renew. Sustain. Energy Rev. 2009, 13, 1275-1287. [CrossRef]

6. Piwowar, A.; Dzikuś, M. Development of Renewable Energy Sources in the Context of Threats Resulting from Low-Altitude Emissions in Rural Areas in Poland: A Review. Energies 2019, 12, 3558. [CrossRef]

7. Zawalińska, K.; Kinnunen, J.; Gradziuk, P.; Celińska-Janowicz, D. To Whom Should We Grant a Power Plant? Economic Effects of Investment in Nuclear Energy in Poland. Energies 2020, 13, 2687. [CrossRef]

8. Zhai, R.; Hu, J.; Saddler, J.N. What are the major components in steam pretreated lignocellulosic biomass that inhibit the efficacy of cellulose enzyme mixtures? ACS Sustain. Chem. Eng. 2016, 4, 3429-3436. [CrossRef]

9. Jefferson, M. Sustainable energy development: Performance and prospects. Renew. Energy 2006, 31, 571-582. [CrossRef] 
10. Wyman, C.E.; Dale, B.E. Producing Biofuels via the Sugar Platform. Chem. Eng. Prog. 2015, 111, $45-57$. Available online: https://www.researchgate.net/profile/Bruce_Dale/publication/283872696_Producing_biofu els_via_the_sugar_platform/links/57504a0a08aefe968db72891/Producing-biofuels-via-the-sugar-platform. pdf (accessed on 7 July 2020).

11. Ang, B.W.; Choon, W.L.; Ng, T.S. Energy security: Definitions, dimensions and indexes. Renew. Sustain. Energy Rev. 2015, 42, 1077-1093. [CrossRef]

12. Winzer, C. Conceptualizing energy security. Energy Policy 2012, 46, 36-48. [CrossRef]

13. Ogarek, P. Przyszłość odnawialnych źródeł energii w Polsce w oparciu o Polityke energetyczną Polski do 2040 roku (The future of renewable energy sources in Poland based on Poland's Energy Policy until 2040). In Bezpieczeństwo Energetyczne Polski i Europy Uwarunkowania-Wyzwania-Innowacje; Ruszel, M., Podmiotko, S., Eds.; Instytut Polityki Energetycznej im. I. Łukasiewicza: Rzeszów, Poland, 2019; pp. 98-119. Available online: https://www.instytutpe.pl/wp-content/uploads/2019/10/Bezpiecze\%C5\%84stwo-energetyc zne-Polski-i-Europy-.pdf (accessed on 9 July 2020). (In Polish)

14. Adamczak, K. Energia odnawialna a bezpieczeństwo Polaków (Renewable energy and the security of Poles). Securitologia 2016, 2, 51-61.

15. Instytut Energetyki Odnawialnej. Rynek Fotowoltaiki w Polsce (Market of Fotovoltaic in Poland); Instytut Energetyki Odnawialnej: Warsaw, Poland, 2020. (In Polish)

16. Bódis, K.; Kougias, I.; Jäger-Waldau, A.; Taylor, N.; Szabó, S. A high-resolution geospatial assessment of the rooftop solar photovoltaic potential in the European Union. Renew. Sustain. Energy Rev. 2019, 114, 109309. [CrossRef]

17. Mundo-Hernández, J.; de Celis Alonso, B.; Hernández-Álvarez, J.; de Celis-Carrillo, B. An overview of solar photovoltaic energy in Mexico and Germany. Renew. Sustain. Energy Rev. 2014, 31, 639-649. [CrossRef]

18. Sliz-Szkliniarz, B.; Eberbach, J.; Hoffmann, B.; Fortin, M. Assessing the cost of onshore wind development scenarios: Modelling of spatial and temporal distribution of wind power for the case of Poland. Renew. Sustain. Energy Rev. 2019, 109, 514-531. [CrossRef]

19. Gnatowska, R.; Moryń-Kucharczyk, E. Current status of wind energy policy in Poland. Renew. Energy 2020, 135, 232-237. [CrossRef]

20. Hajto, M.; Cichocki, Z.; Bidłasik, M.; Borzyszkowski, J.; Kuśmierz, A. Constraints on Development of Wind Energy in Poland due to Environmental Objectives. Is There Space in Poland for Wind Farm Siting? Environ. Manag. 2019, 59, 204-217. [CrossRef]

21. Wielewska, I. Rozwój OZE na obszarach wiejskich i ich wpływ na środowisko przyrodnicze w opinii doradców rolnych (The development of RES in rural areas and their impact on the natural environment, in the opinions of agricultural advisors). Problemy Rolnictwa Światowego 2014, 14, 186-195.

22. Przybylska-Czastkiewicz, M. Prawne uwarunkowania rozwoju energetyki odnawialnej w Polsce po 2015 r. (Legal conditions for the development of renewable energy in Poland after 2015). Polityka Energetyczna Energy Policy J. 2017, 20, 103-116.

23. Marks-Bielska, R.; Bielski, S.; Novikova, A.; Romaneckas, K. Straw Stocks as a Source of Renewable Energy. A Case Study of a District in Poland. Sustainability 2019, 11, 4714. [CrossRef]

24. Jankowski, K.J.; Sokólski, M.M.; Dubis, B.; Załuski, D.; Szempliński, W. Sweet sorghum—Biomass production and energy balance at different levels of agricultural inputs. A six-year field experiment in north-eastern Poland. Eur. J. Agron. 2020, 119, 126119. [CrossRef]

25. Schallenberg Rodríguez, J.C.; Piernavieja Izquierdo, G.; Hernández Rodríguez, C.; Unamunzaga Falcón, P.; García Déniz, R.; Díaz Torres, M.; Cabrera Pérez, D.; Martel Rodríguez, G.; Pardilla Fariña, J.; Subiela Ortin, V. Energías Renovables y Eficiencia Energética; Instituto Tecnológico de Canarias, S.A.: Santa Cruz, Spain, 2008. Available online: https://www.cienciacanaria.es/files/Libro-de-energias-renovables-y-eficiencia-energetica. pdf (accessed on 9 July 2020).

26. Lewandowski, W. Proekologiczne Odnawialne Źródła Energii (Pro-Ecological Renewable Energy Sources); WNT: Warszawa, Poland, 2014. (In Polish)

27. Hodana, M.; Holtzer, G.; Kalandyk, K.; Szymańska, A.; Szymański, B.; Żymankowska-Kumon, S. Odnawialne Źródła Energii. Poradnik (Renewable Energy Sources. Guide); HELIOS: Kraków, Poland, 2012. Available online: http://home.agh.edu.pl/ \{\}szk/files/docs/OZE_poradnik.pdf (accessed on 9 July 2020). (In Polish) 
28. Villanueva Rodríguez, T. El Carbón. Junta de Castilla y León, UMINSA, M.S.P., S.A. HVL, Grupo Viloria, APEMA, UEE. 2009. Available online: https://www.siemcalsa.com/images/pdf/El\%20Carbon.pdf?fbclid=Iw AR2BemdGhi3LbAvaBF5xc4BVfFUQE8eWbI54j_Ojpk4YDbMirb8yvNZjG4M (accessed on 14 July 2020).

29. Wilczyński, M. Zmierzch Węgla Kamiennego w Polsce (Twilight of Hard Coal in Poland); Fundacja Instytut Na rzecz Ekorozwoju: Warszawa, Poland, 2013. Available online: file://C:/Users/UWM/AppData/Local/Temp/ ESP\%20nr\%2006_2017_04.pdf (accessed on 9 July 2020). (In Polish)

30. Kasztelewicz, Z.; Tajduś, A.; Słomka, T. Węgiel brunatny to paliwo przyszłości czy przeszłości? (Lignite is the fuel of the future or the past?). Napędy $i$ Sterowanie 2017, 19, 88-104.

31. Dubiński, J.; Turek, M.; Aleksa, H. Węgiel kamienny dla energetyki zawodowej w aspekcie wymogów ekologicznych [Energy security in national and EU legal regulations]. Górnictwo i Środowisko 2005, 2, 5-21.

32. Kaliski, M.; Nagy, S.; Rychlicki, S.; Siemek, J.; Szurlej, A. Gaz ziemny w Polsce-Wydobycie, zużycie do 2030 roku (Natural gas in Poland-Extraction, consumption by 2030). Górnictwo i Geologia 2010, 5, 27-40. Available online: https://www.polsl.pl/Wydzialy/RG/Wydawnictwa/Documents/kwartal/5_3_2.pdf (accessed on 9 July 2020). (In Polish).

33. Wilczyński, M. Gaz Ziemny Wsparciem dla Niskoemisyjnej Gospodarki (Natural Gas Supports Low-Carbon Economy); Instytut na rzecz Ekorozwoju: Warszawa, Poland, 2015. Available online: https://www.teraz-srodowisko.pl/ media/pdf/aktualnosci/1585-gaz-ziemny-wsparcie-niskoemisyjnej-gospodarki.pdf (accessed on 9 July 2020). (In Polish)

34. Kiełbasa, W.; Szyszka, R.; Bonisławski, W.; Kołodziej, W. Podstawy Energetyki Jadrowej (Basics of Nuclear Power); Hydroenergo: Wejherowo, Poland, 2012. Available online: http://static.scholaris.pl/main-file/107/311/podsta wy_energetyki_jadrowej_67730.pdf (accessed on 9 July 2020). (In Polish)

35. Gędek, S.; Ruszel, M. Ocena bezpieczeństwa ekonomicznego polskiego sektora ropy naftowej-Stan i perspektywy (Assessment of the economic security of the Polish oil sector-Condition and prospects). Zeszyt Naukowy Instytutu Gospodarki Surowcami Mineralnymi i Energia Polskiej Akademii Nauk 2016, 95, $265-274$.

36. Departament Energii Jądrowej Ministerstwa Energii. Wydobycie i Produkcja Uranu. Program Jadrowy na Ukrainie (Uranium Mining and Production. Nuclear Program in Ukraine); Departament Energii Jądrowej Ministerstwa Energii: Ukraina, Program Polskiej Energetyki Jądrowej Analizy i Opracowania; 2016. Available online: file://C:/Users/UWM/AppData/Local/Temp/5_Uran_Ukraina-3.pdf (accessed on 9 July 2020). (In Polish)

37. Berent-Kowalska, G.; Kacprowska, J.; Moskal, I.; Piwko, D.; Jurgaś, A.; Kacperczyk, G. Energia ze Źródet Odnawialnych 2016 r. (Renewable Energy 2016); Główny Urząd Statystyczny: Warszawa, Poland, 2017. Available online: https:/stat.gov.pl/files/gfx/portalinformacyjny/pl/defaultaktualnosci/5485/3/11/1/energia_ ze_zrodel_odnawialnych_2016.pdf (accessed on 9 July 2020). (In Polish)

38. Maśloch, G. Uwarunkowania i Kierunki Rozwoju Energetyki Odnawialnej w Polsce (Conditions and Directions of Development of Renewable Energy in Poland); Szkoła Główna Handlowa: Warszawa, Poland, 2018. (In Polish)

39. Tokarz, J.; Hryckiewicz, L. Elektrownia Wodna Żarnowiec-Historia i dzień dzisiejszy (Żarnowiec Hydroelectric Power Plant-History and today). Energetyka 2003, 8, 509-515. Available online: http://elektroenergetyka.pl/upl oad/file/2003/8/elektroenergetyka_nr_03_08_1.pdf (accessed on 9 July 2020). (In Polish).

40. Niechciał, J. Energetyka wodna-Jak wpływa na środowisko? (Hydropower-How does it affect the environment?). Wszechświat 2014, 115, 209-211.

41. Krzemień, Z. Wykorzystanie energii fal morskich do produkcji energii elektrycznej (Sea wave energy using for electrical energy production). Pr. Inst. Elektron. 2013, 262, 120-131.

42. Kiernicki, J.; Bałuka, G. Energia wiatru jako szczególne źródło energii odnawialnej (Wind energy as a special source of renewable energy). Energetyka 2009. Available online: https://www.cire.pl/pliki/2/eowbaluka.pdf (accessed on 9 July 2020). (In Polish).

43. Mularczyk, A.; Hysa, B. Rozwój i perspektywy energii solarnej w Polsce i województwie śląskim (Development and perspectives of solar energy in Poland and the Ślaskie Voivodeship). Zeszyt Naukowy Politechniki Śląskiej Organizacja i Zarzadzanie 2015, 86, 363-377.

44. Ustawa z Dnia 7 Czerwca 2018 r. o Zmianie Ustawy o Odnawialnych Źródłach Energii Oraz Niektórych Innych Ustaw (Act of 7 June 2018 Amending the Act on Renewable Energy Sources and Some Other Acts) (Dz.U. z 2018, Poz. 1276). Available online: https://isap.sejm.gov.pl/isap.nsf/download.xsp/WDU2016000083 1/T/D20160831L.pdf (accessed on 9 July 2020). (In Polish)

45. Mirowski, T.; Mokrzycki, E.; Uliasz-Bocheńczyk, A. Energetyczne Wykorzystanie Biomasy (Energetic Use of Biomass); IGSMiE PAN: Kraków, Poland, 2018. (In Polish) 
46. Sala, K. Przemysłowe wykorzystanie energii geotermalnej w Polsce na przykładzie geotermalnego zakładu ciepłowniczego w Bańskiej Niżnej (Industrial use of geothermal energy in Poland on the example of a geothermal heating plant in Bańska Niżna). Prace Komisji Geografii Przemysłu Polskiego Towarzystwa Geograficznego 2018, 32, 74-82.

47. Graczyk, A. Rozwój odnawialnych źródeł energii w polskiej polityce regionalnej. (Development of renewable energy sources in Polish regional policy). Barometr Regionalny 2017, 15, 4-59. Available online: http://br.wszia.edu.pl/zeszyty/pdfs/br50_07graczyk.pdf (accessed on 7 July 2020). (In Polish).

48. Zalega, T. Wykorzystanie odnawialnych źródeł energii w gospodarstwach seniorów w Polsce w świetle wyników badań (The use of renewable energy sources in senior farms in Poland in the light of research results). In Rola Odnawialnych Źródeł Energii e Rozwoju Społeczno-Ekonomicznym Kraju i Regionów; Nowak, A.Z., Szałański, M., Zborowska, W., Eds.; Wydawnictwo Naukowe Wydziału Zarządzania Uniwersytetu Warszawskiego: Warszawa, Poland, 2016. Available online: https://depot.ceon.pl/bitstream/handle/1 23456789/13428/Rola\%20odnaw.\%20zrodel\%20energii\%20DRUK.pdf?sequence=1\&isAllowed=y (accessed on 9 July 2020). (In Polish)

49. Available online: https://encyklopedia.pwn.pl/haslo/bilans-energetyczny;3877634.html (accessed on 14 April 2020).

50. GUS. Energia ze Źródeł Odnawialnych w 2017 r. (Renewable Energy 2017); GUS: Warszawa, Poland, 2018. Available online: https://stat.gov.pl/obszary-tematyczne/srodowisko-energia/energia/energia-ze-zrodel-od nawialnych-w-2018-roku,10,2.html (accessed on 9 July 2020). (In Polish)

51. GUS. Energia ze Źródeł Odnawialnych 2018 r. (Renewable Energy 2018); GUS: Warszawa, Poland, 2019. Available online: file://C:/Users/UWM/AppData/Local/Temp/energia_ze_zrodel_odnawialnych_w_2018.pdf (accessed on 9 July 2020). (In Polish)

(C) 2020 by the authors. Licensee MDPI, Basel, Switzerland. This article is an open access article distributed under the terms and conditions of the Creative Commons Attribution (CC BY) license (http://creativecommons.org/licenses/by/4.0/). 